\title{
Nursing dress code and perception of a nurse by patients
}

Pielęgniarski dress code a postrzeganie osoby pielęgniarki przez pacjentów

\author{
Piotr Pawłowski', Paulina Mazurek', Magdalena Zych', Katarzyna Zuń2, \\ Beata Dobrowolska3
}

\begin{abstract}
'Students'Scientific Association, Department of Nursing Development, Faculty of Health Sciences, Medical University of Lublin/ Studenckie Koło Naukowe przy Katedrze Rozwoju Pielęgniarstwa, Wydział Nauk o Zdrowiu Uniwersytetu Medycznego w Lublinie 2Department of Pathology Infants University Children's Hospital in Lublin/ Oddział Patologii Niemowląt, Uniwersytecki Szpital Dziecięcy w Lublinie ${ }^{3}$ Department of Nursing Development, Faculty of Health Sciences, Medical University of Lublin/ Katedra Rozwoju Pielęgniarstwa, Wydział Nauk o Zdrowiu Uniwersytetu Medycznego w Lublinie

CORRESPONDING AUTHOR/AUTOR DO KORESPONDENCJI:

Piotr Pawłowski

Studenckie Koło Naukowe przy Katedrze Rozwoju Pielęgniarstwa Wydział Nauk o Zdrowiu Uniwersytetu Medycznego w Lublinie

ul. Staszica 4/6, 20-250 Lublin

e-mail: pawlowskipiotr56@gmail.com
\end{abstract}

STRESZCZENIE PIELĘGNIARSKI DRESS CODEA POSTRZZEGANIE OSOBY PIELĘGNIARKI PRZZZ PACJENTÓW

Wprowadzenie. Wizerunek zawodowy pielęgniarki w opinii pacjentów uwarunkowany jest wieloma zmiennymi, w tym także umundurowaniem zawodowym. Godne reprezentowanie profesji pielęgniarki jest powinnością osób sprawujących opiekę nad pacjentem.

Cel pracy. Określenie wpływu dress code na kształtowanie wizerunku zawodowego pielęgniarek w opinii pacjentów.

Materiał i metodyka. W pracy posłużono się metodą niesystematycznego przeglądu dostępnego piśmiennictwa. Dane uzyskano poprzez przeszukanie internetowych baz, takich jak: Google Scholar, PubMed, CINAHL Complete oraz elektronicznych zasobów czasopism pielęgniarskich.

Wyniki. W percepcji hospitalizowanych pacjentów pielęgniarki dress code wpływa na poziom zaufania do osób sprawujących opiekę, jest ważnym elementem oceny ich profesjonalizmu, wiedzy, czy pewności w wykonywaniu określonych interwencji medycznych. Dostosowany do potrzeb, odpowiednio dobrany styl umundurowania zawodowego pielęgniarki umożliwia właściwą jej identyfikację na tle pozostałych członków zespołu terapeutycznego, czy pracowników administracyjnych. Dodatkowo, komfort pielęgniarek jest dla pacjentów istotną wartością w planowaniu strategii dress code, często determinuje on profesjonalizm oraz jakość świadczonych usług. Wnioski. Istnieje związek między wyglądem zewnętrznym pielęgniarek, a ich wizerunkiem zawodowym oraz postrzeganiem przez pacjentów kompetencji zawodowych i poziomu profesjonalizmu. Dress code w placówce opieki zdrowotnej może stanowić istotny element polityki wizerunkowej zarówno placówki systemu ochrony zdrowia, jak i grupy zawodowej pielęgniarek.

Słowa kluczowe: mundur pielęgniarski, dress code, wizerunek zawodowy, prestiż zawodowy, zawody medyczne

ABSTRACT NURSING DRESS CODE AND PERCEPTION OF A NURSE BY PATIENTS

Introduction. Professional image of the nurse in the opinion of the patient community is conditioned by many variables, including professional attire. A worthy representation of the nurse profession is the responsibility of all those who care for the patient.

Aim. Determining the impact of dress code on shaping the professional image of nurses in the opinion of patients.

Material and methods. Non-systematic review method of the literature available. The data was obtained by searching online databases, such as: Google Scholar, PubMed, CINAHL Complete as well as electronic resources of nursing magazines.

Results. In the perception of hospitalized patients, the nursing dress code affects the level of trust in those who care for patients, it also constitutes an important element in assessing their professionalism, knowledge or confidence when performing specific medical interventions. Adapted to the needs, a suitably selected style of professional attire of a nurse employed in a given health care facility enables her proper identification of them against the background of other members of the therapeutic team or administrative employees. In addition, the comfort of nurses is a significant factor for patients in dress code strategy planning; it often determines professionalism and quality of services provided.

Conclusions. There is a relationship between the external appearance of nurses and their professional image and the patients' perception of their professional skills as well as the level of their professionalism. Dress code in a health care facility may constitute a significant element of image policy for both a health care facility itself and a group of nurses.

Key words: nurse attire, dress code, professional image, professional prestige, medical professions 


\section{INTRODUCTION}

The professional image of nurses is shaped by many determinants. One of them is the so-called dress code, and therefore, the style of professional attire. The external appearance is directly related to the concept of comfort, occupational health and safety, as well as the issue of identifying nurses against the background of other members of the therapeutic team or administrative staff of a given medical facility. The external appearance also shapes a positive or negative image of the representatives of a given profession, thus affecting the professional prestige of a group of professionals in question. The visual appearance of each group of professionals involves all kinds of beliefs, opinions and stereotypes prevailing in society. The patient's very first impressions of the doctor and nurse significantly influence the creation of an appropriate therapeutic relationship, essential to the proper implementation of the holistic process of nursing the patients, regardless of the place of their treatment. The aim of this paper is to analyze the impact of the style of professional attire on the perception of a nurse by a patient.

\section{MATERIALS AND METHODS}

The non-systematic review and analysis of the Polishand English-language scientific literature were conducted. The electronic databases i.e. Google Scholar, PubMed, CINAHL Complete and electronic resources of nursing magazines covering the past 20 years have been searched. The search was conducted according to the combination of keywords in Polish and English such as nurse attire, nurse's prestige, professional image. The number of 11 papers dealing with the subject of nursing dress code was analyzed. The papers were of a study type coming from Western countries, mainly the United States. The respondents of the study were patients of different ages, gender and reasons for hospitalization, and the subject concerned the perception of nurses by patients depending on the nurse attire as well as its role in shaping the professional image. The basic methodological data of the selected papers is presented in Table 1. The role of the color scheme of professional attire as well as wearing jewelry and make-up were highlighted in creating an appropriate therapeutic relationship with the patient being the subjected to medical care. Also, an important issue in the analysis of the literature has become the identification of members of the nursing team compared to other employees of medical facilities. Occupational health and safety, epidemiological aspects and comfort also constitute the factors evaluated by patients in the analyzed studies.

\section{RESULTS}

\section{Problems with the identification of a nurse among the other medical employees}

Over the years, the nursing dress code has changed. In the 20th century, the nurse was obliged to wear a white coat, and above all a nurse's cap, as a symbol of her profession. In the course of the evolution of the nursing ethos and the abolition of the tradition of uniform attire, the problem of identifying nurses against the background of the other members of the therapeutic team or administrative employees of health care institutions has appeared. Studies show that patients are confused. They have difficulties in distinguishing a nurse, a medical caretaker, or administrative staff of a hospital or other facility in the health care system. Elderly people accustomed to traditional nurse attire, in which a nurse's cap was the basis for identification, have the most difficulty in adapting to the present state, in which there is absolute freedom in nurse attire and the only way to indicate is the ID [1].

Studies conducted in the United Kingdom drew attention to the disturbing process undergoing in society. An elderly patient who saw a nurse in a different uniform than a traditional one with a cap on their head, often questioned the knowledge, skills, competence, commitment, care and, hence, professionalism of a nurse. These conclusions prompted the authors to broaden their studies. The NIS - Nursing Incivility Scale was developed, with the help of which studiers found that informal nurse attire does not represent her professional identity clearly. It was also proven that the concept of nursing dress code is directly related to the aspect of perception of a nurse as a qualified, competent person to perform activities related to the chosen profession. Patients who are nursing care recipients often look for evidence of competence, honesty and care in non-verbal messages sent by a nurse. These include, inter alia, her style of professional attire, appearance, possession of tattoos, earrings and even the length of hair. A common phenomenon in patients admitted to a hospital ward is the fear of hospitalization. The patient expects clues, clear signs, often even the evidence, assuring him of the authority, a high level of professional ethics, and above all, the professionalism of the people who care for him/her. Numerous studies on the perception of nurses by patients show that the level of their competence and professionalism in the eyes of patients is based on the first impression, projecting in the future on the level of their trust in those who care for them, and thus the creation of a high-quality therapeutic relationship [2].

\section{Color scheme of nurse attire - influence on the patient's opinion}

The color scheme of the nurse attire is an important element in creating an opinion about the person of a nurse in the perception of the patient and their family. Küçük L. et al. created a catalog of 8 patterns of nurse attire, varied in terms of color scheme and fabric texture, by means of which the preferences of patients with mental disorders regarding nurse attire were examined. When it comes to $31 \%$ of the respondents of this study, they prefer white as a color characteristic of employees of health care institutions. The authors, as the reason for this state, argue that white attire, in the perception of the patient, indicates the nurse's professionalism as well as having adequate knowledge and experience, which translate into effectiveness in action and a high level of self-confidence. In addition, white is identified with cleanliness and hygiene, which affects the high sense of epidemiological safety of the care 
Tab. 1. Description of the selected papers analyzed

\begin{tabular}{|c|c|c|c|c|c|c|c|}
\hline No. & Authors & Title & $\begin{array}{c}\text { Year of } \\
\text { publication }\end{array}$ & Aim & $\begin{array}{l}\text { Study } \\
\text { method }\end{array}$ & Study tools & Study group \\
\hline 1. & $\begin{array}{c}\text { Lehna C., Pfoutz S., } \\
\text { Peterson TG., Degner K., } \\
\text { Grubaugh K.,Lorenz L, } \\
\text { Mastropietro S., Rogers LS., } \\
\text { Schoettle B, Seck LL. }\end{array}$ & $\begin{array}{l}\text { Nurse attire: indicators of } \\
\text { professionalism. }\end{array}$ & 1999 & $\begin{array}{l}\text { Impact study on the way } \\
\text { the current nurse's attire, } \\
\text { affects the image of the } \\
\text { nurse profession. }\end{array}$ & Interview & $\begin{array}{l}\text { Interview form, } \\
\text { dictaphone }\end{array}$ & $\begin{array}{c}12 \text { nurses, } \\
1 \text { student of } 1^{\text {st level, }} \\
1 \text { adult patient }\end{array}$ \\
\hline 2. & $\begin{array}{l}\text { Skorupski VJ., } \\
\text { Rea RE. }\end{array}$ & $\begin{array}{c}\text { Patient perceptions of today's } \\
\text { nurse attire: Exploring dual } \\
\text { images }\end{array}$ & 2006 & $\begin{array}{l}\text { Defining the image of a } \\
\text { nurse depending on her } \\
\text { attire. }\end{array}$ & $\begin{array}{l}\text { Diagnostic } \\
\text { survey }\end{array}$ & $\begin{array}{l}\text { 13-point author's } \\
\text { questionnaire form }\end{array}$ & \begin{tabular}{|c|}
180 adult \\
patients of the \\
Pacific Northwest \\
Hospital \\
\end{tabular} \\
\hline 3. & $\begin{array}{c}\text { Albert NM., Wocial L., } \\
\text { Meyer KH., Trochelman K. }\end{array}$ & $\begin{array}{l}\text { Impact of nurses' uniforms } \\
\text { on patient and family } \\
\text { perceptions of nurse } \\
\text { professionalism. }\end{array}$ & 2008 & $\begin{array}{c}\text { Evaluation of nurse's } \\
\text { professional level } \\
\text { depending on her uniform. }\end{array}$ & $\begin{array}{l}\text { Diagnostic } \\
\text { survey }\end{array}$ & $\begin{array}{l}\text { Nurse Image Scale } \\
\text { (NIS), Nurse Image } \\
\text { Scale (NIS) }\end{array}$ & $\begin{array}{l}390 \text { adult } \\
\text { patients, their } \\
\text { adult visitors, } \\
109 \text { pediatric } \\
\text { patients }\end{array}$ \\
\hline 4. & $\begin{array}{l}\text { Guidroz AM., } \\
\text { Burnfield-Geimer JL. } \\
\text { Clark 0., Schwetschenau } \\
\text { HM. Jex SM. }\end{array}$ & $\begin{array}{c}\text { The Nursing Incivility Scale: } \\
\text { Development and Validation } \\
\text { of an Occupation-Specific } \\
\text { Measure }\end{array}$ & 2010 & $\begin{array}{c}\text { Evaluation of the } \\
\text { development of Nursing } \\
\text { Incivility Scale, its validity } \\
\text { and applications. }\end{array}$ & $\begin{array}{l}\text { Diagnostic } \\
\text { survey, scale } \\
\text { validation }\end{array}$ & $\begin{array}{l}\text { Nursing Incivility } \\
\text { Scale (NIS) }\end{array}$ & 163 nurses \\
\hline 5. & Castledine G. & Uniformity in uniform & 2011 & $\begin{array}{l}\text { The author's reflections } \\
\text { on uniformity in nursing } \\
\text { professional attire }\end{array}$ & $\begin{array}{l}\text { Literature } \\
\text { overview }\end{array}$ & - & - \\
\hline 6. & Sharkey V. & Uniform approach & 2012 & $\begin{array}{c}\text { Analysis of the nursing } \\
\text { professional attire }\end{array}$ & $\begin{array}{l}\text { Literature } \\
\text { overview }\end{array}$ & - & - \\
\hline 7. & $\begin{array}{l}\text { Albert NM., Burke J., } \\
\text { Bena JF. Morrison SM. } \\
\text { Forney J. Krajewski S. }\end{array}$ & $\begin{array}{c}\text { Nurses' Uniform Color } \\
\text { scheme and Feelings/Emot- } \\
\text { ions in School-Aged Children } \\
\text { Receiving Health Care }\end{array}$ & 2013 & $\begin{array}{c}\text { Analysis of the emotional } \\
\text { response of pediatric } \\
\text { patients depending on the } \\
\text { color scheme of professional } \\
\text { attire. } \\
\end{array}$ & $\begin{array}{l}\text { Diagnostic } \\
\text { survey }\end{array}$ & $\begin{array}{c}\text { Author's questionnaire } \\
\text { form }\end{array}$ & $\begin{array}{l}233 \text { pediatric } \\
\text { patients }\end{array}$ \\
\hline 8. & $\begin{array}{c}\text { Clavelle JT., } \\
\text { Goodwin M., Tivis LJ. }\end{array}$ & $\begin{array}{l}\text { Nursing Professional Attire } \\
\text { Probing Patient Preferences } \\
\text { to Inform Implementa-tion }\end{array}$ & 2013 & \begin{tabular}{|} 
Broadening the knowledge \\
of the perception of \\
a professional image \\
of nurses regarding \\
professional attire. \\
\end{tabular} & $\begin{array}{l}\text { Diagnostic } \\
\text { survey }\end{array}$ & $\begin{array}{c}\text { Modified Penn } \\
\text { Interactive Peer Play } \\
\text { Scale (PIPPS) with one } \\
\text { open question. }\end{array}$ & $\begin{array}{l}350 \text { adult } \\
\text { patients }\end{array}$ \\
\hline 9. & $\begin{array}{l}\text { Hoeve tY, Jansen G., } \\
\text { Roodbol P. }\end{array}$ & $\begin{array}{l}\text { The nursing profession: } \\
\text { public image, self-concept } \\
\text { and professional identity. A } \\
\text { discussion paper. }\end{array}$ & 2013 & $\begin{array}{c}\text { Discussing the actual } \\
\text { image of nurses. Analysis } \\
\text { of other factors influencing } \\
\text { the development of self- } \\
\text { assessment of nurses and } \\
\text { professional identity. }\end{array}$ & $\begin{array}{l}\text { Systematic } \\
\text { review of } \\
\text { available } \\
\text { literature }\end{array}$ & - & $\begin{array}{l}1216 \text { articles have } \\
\text { been qualified, } \\
18 \text { of them meet } \\
\text { the inclusion } \\
\text { criteria for } \\
\text { analysis. } \\
\end{array}$ \\
\hline 10. & $\begin{array}{l}\text { Porr C., Dawe D., } \\
\text { Lewis N., Meadus RJ., } \\
\text { Snow N., Didham P. } \\
\end{array}$ & $\begin{array}{c}\text { Patient perception of } \\
\text { contemporary nurse attire: } \\
\text { A pilot study }\end{array}$ & 2014 & $\begin{array}{c}\text { Analysis of patients' } \\
\text { opinions on the nurse attire }\end{array}$ & $\begin{array}{c}\text { Diagnostic } \\
\text { survey } \\
\text { (a pilot study) } \\
\end{array}$ & $\begin{array}{l}\text { Modified Nurse Image } \\
\text { Scale (MNIS) }\end{array}$ & $\begin{array}{l}46 \text { adult surgical } \\
\text { patients }\end{array}$ \\
\hline 11. & $\begin{array}{l}\text { Küçüka L. Çömeza T., } \\
\text { Kaçarb S., Sümelib F., } \\
\text { Taşkıran 0̈. }\end{array}$ & $\begin{array}{l}\text { Psychiatric Patients' } \\
\text { Perspective: Nursing } \\
\text { Uniforms. }\end{array}$ & 2015 & $\begin{array}{c}\text { Examination of the } \\
\text { influence of the color } \\
\text { scheme of a professional } \\
\text { nurse attire on a } \\
\text { psychiatrically hospitalized } \\
\text { patient } \\
\end{array}$ & $\begin{array}{l}\text { Diagnos-tic } \\
\text { survey (cross- } \\
\text { sectional } \\
\text { studies) }\end{array}$ & $\begin{array}{l}\text { Nursing Uniform } \\
\quad \text { Catalog }\end{array}$ & $\begin{array}{l}257 \text { adult } \\
\text { patients treated } \\
\text { psychiatrically }\end{array}$ \\
\hline
\end{tabular}

provider. Moreover, in all religions and religious movements, white is identified with purity, gentleness, and even sanctity, which enables the nurse to provide holistic care, based on trust and proper communication involving the spiritual aspect of care. Also, an interesting fact is that in the study as many as $15 \%$ of respondents indicated the preference for the civilian outfit of nurses, motivating their choice with communication barriers, disrupting the relationship between the patient and members of the nursing team [3].

Nurses themselves also prefer white as a color scheme characteristic of employees of the health care system, which also allows their easy and quick identification from among the other employees of medical facilities [3].
Lehna et al. in a qualitative study, using the free interview method with 12 nurses and 1 patient, proved the relationship between white uniforms and the ease of identification. The female patient who was the respondent of the study was confused when the nurses were not wearing the clothing facilitating their identification. Nurses participating in the study also recognized the professional uniform as an important aspect of their identification [4].

Porr C. et al. conducted a study to illustrate how the nursing dress code affects the professionalism and perception of the nurse. The study involved 449 patients of all ages. As a study tool, a Modified Nurse Image Scale was used with 10 features influencing professionalism, including: confidence, competence, mindfulness, 
approachability, reliability, professionalism, ability to cooperate and empathy. Each of the respondents was presented with a photograph, which was then to be assessed according to the abovementioned scale. The analysis of the conducted study showed some dependencies, between the color schemes, the texture of the uniforms, and the level of 10 features related to the professionalism of the nurse profession. The highest results were obtained by shades of white. Relatively high results in the level of the relevant features were obtained by uniform attire in shades of blue, also identified with a person who is highly trusted. The lowest results were obtained by attire having of varied colorful texture $[1,5]$.

\section{Age as a variable determining preferences in the nursing dress code}

Study by Skorupski et al. shows the relationship between age and preferences regarding a professional attire of the nurse. Based on the obtained empirical data, it was concluded that people from the baby boomers generation and seniors identify nurses with a white uniform. However, younger people identify nurses by reading name tags or badges placed on their attire in the United Kingdom and the United States. In addition, this study also assessed selected nurse attire using the NIS (Nursing Incivility Scale) modified by S. Mangum. Its modification enabled to indicate the dependencies of how the texture and color scheme of attire affect the features that the patient, who is the subject of nursing care, receives in their perception. The received numerical data led to the conclusion that the attire the least desirable by patients is plain one without any texture, and colors other than white $[2,6]$.

Albert N. M. et al. conducted studies on the impact of professional nurse attire style on patients' opinions. Respondents of the study comprised adults and children. Age constituted an independent variable, by means of which the difference in the perception of nurses shown in photographs was presented [7]. Among adults, the highest score $(25 \%)$ was obtained by white attire of nurses, while the lowest score was obtained by the attire where one could see clearly the texture of the fabric. Different results were obtained in the group of pediatric patients, the highest score $(22 \%)$ was obtained by a textured top with white or blue trousers $[7,8]$.

\section{Other important aspects of the nurse's image affecting their perception in the eyes of the hospitalized patient}

In the study conducted by Clavelle J. et al., with participation of 350 patients, a diagnostic survey was used. The study tool was a questionnaire form containing 13 items from PIPPS (Penn Interactive Peer Play Scale) where 4 of them refer to the nurse's professionalism, 5 of them address the issue of patients' preferences regarding the style of attire. Each of the 13 items in the questionnaire was rated by a respondent with the use of the Likert scale from 1 to 10 , where 1 meant „I strongly disagree” and 10 - „I strongly agree”. In addition, the questionnaire included one open question: „Do you think there is anything else that should be considered when assessing the nurse attire?" The aim of the study was to show whether the nurse attire influenced the patient's perception of the nurse as a professional. After analyzing the results general conclusions were drawn. Patients pay a lot more attention to many other features than the color scheme of the attire, namely, the neatness of the appearance of nurses, referring to ironed, uncreased attire and clean shoes. An important aspect has become the length of hair, which according to patients should not exceed the shoulder length. Nurses wearing strong make-up, body piercing, tattoos, long nails, intense perfume and lots of jewelry were perceived as less empathetic, impatient, possessing a lower level of skills and competence, although the above-mentioned elements of external appearance were not very popular among nurses. The analyzed study has shown that the comfort of nurses is an important value for patients in dress code strategy planning, because its level directly affects the quality of services provided [9].

\section{DISCUSSION}

The introduction of dress code in Western Europe and the United States led to many controversies in the past. Until now the strategies of unified professional nurse attire have both their supporters and opponents. The main problem with the introduction of the nursing dress code, quoted in the literature, is the necessity of updating it. It is important for the nurse attire to follow trends and broadly understand fashion, and above all to be practical, not to hinder movements, to ensure the safety of both the patients and the nurses themselves. Another argument of the opponents of introducing uniform nurse attire is the opinion that nursing is the profession encompassing care, requiring interdisciplinary skills in the field of medicine and social sciences from its professionals, and the fact of wearing the proper attire does not affect the possession of the skills in question [10].

The introduction of dress code policy for nurses is also associated with additional, high costs of purchasing new uniform attire. Finding additional funds for this purpose would be possible only with the support of the employers and the state. Currently, nurses in Western countries such as the United Kingdom, receive their uniforms from an employer themselves in the form of 5 tunics or jackets and 3 pairs of trousers. They are entitled to deduct all the costs of their maintenance, including the cost of maintaining their attire clean, from the income tax withheld in the annual tax return $[11,12]$.

The issue of nurse attire is a current problem for nursing leaders. Many organizational units of the healthcare system are still considering the introduction of dress code policy applicable to all representatives of medical professions, and thus facilitating their identification. The right choice of nurse attire can positively influence the social welfare of a given health care facility, nurses and leaders, managing teams of professionals. Considering the above, it is crucial that the strategy introducing changes to the attire bears the features of an organized process which is thoughtful and consistent [13]. 


\section{CONCLUSIONS}

1. There is a relationship between the external appearance of nurses at work and their professional image. What matters, is the style of the attire, its color scheme, aesthetics and uniformity in a health care facility.
2. There is also a relationship between the external appearance of the nurse at work and the patients' perception of their professional skills as well as the level of their professionalism.

3. Nurse attire in a health care facility may constitute a significant element of image policy for both a health care facility itself and a group of nurses in question.

\section{Pielęgniarski dress code a postrzeganie osoby pielęgniarki przez pacjentów}

\section{WPROWADZENIE}

Wizerunek zawodowy pielęgniarek kształtowany jest przez wiele determinantów. Jednym $z$ nich jest tzw. dress code, a więc styl umundurowania zawodowego. $\mathrm{Z}$ wyglądem zewnętrznym bezpośrednio wiążą się pojęcie wygody, bezpieczeństwa i higieny pracy, a także problematyka identyfikacji pielęgniarek na tle pozostałych członków zespołu terapeutycznego, czy pracowników administracyjnych danej placówki medycznej. Wygląd zewnętrzny kształtuje również pozytywny bądź negatywny obraz reprezentantów określonej profesji, wpływając tym samym na prestiż zawodowy tej grupy profesjonalistów. $\mathrm{Z}$ wizualną prezencją każdej grupy zawodowej wiążą się wszelkiego rodzaju przekonania, opinie, stereotypy panujące w społeczeństwie. Pierwsze odczucia pacjenta wobec osoby lekarza, pielęgniarki znacząco wpływają na wytworzenie stosownej relacji terapeutycznej, niezbędnej do właściwego realizowania holistycznego procesu pielęgnowania pacjenta, niezależnie od miejsca jego leczenia. Celem niniejszej pracy jest analiza wpływu stylu umundurowania zawodowego na postrzeganie pielęgniarki przez pacjenta.

\section{MATERIAŁ I METODYKA}

Dokonano niesystematycznego przeglądu i analizy piśmiennictwa naukowego polsko- i anglojęzycznego. Przeszukano elektroniczne bazy danych tj.: Google Scholar, PubMed, CINAHL Complete oraz elektroniczne zasoby czasopism pielęgniarskich z ostatnich 20 lat. Przeszukiwanie przeprowadzono według kombinacji słów kluczowych w języku polskim i angielskim: mundur pielęgniarski, prestiż pielęgniarki, wizerunek zawodowy. Przeanalizowano 11 artykułów poruszających tematykę pielęgniarskiego dress code. Prace te miały charakter prac badawczych, pochodzących z krajów zachodnich, głównie Stanów Zjednoczonych. Respondentami badań byli pacjenci zróżnicowani pod względem wiekowym, płci oraz powodu hospitalizacji, ich przedmiot natomiast dotyczył postrzegania pielęgniarek przez pacjentów w zależności od ich umundurowania, a także jego roli w kształtowaniu wizerunku zawodowego. Podstawowe dane metodologiczne wyszukanych prac przedstawiono w Tabeli 1. Zwrócono uwagę na rolę kolorystyki umundurowania zawodowego, posiadania biżuterii oraz makijażu $\mathrm{w}$ tworzeniu stosownej relacji terapeutycznej z pacjentem będącym podmiotem opieki. Ważnym zagadnieniem w analizie piśmiennictwa stała się także identyfikacja członków zespołu pielęgniarskiego na tle innych pracowników placówek medycznych. Bezpieczeństwo i higiena pracy, aspekty epidemiologiczne, wygoda, to czynniki także oceniane przez pacjentów w analizowanych badaniach.

\section{WYNIKI}

\section{Problemy z identyfikacją pielęgniarki wśród innych pracowników medycznych}

Na przestrzeni lat pielęgniarski dress code ulegał zmianie. W XX wieku pielęgniarka miała obowiązek noszenia białego fartucha, a przede wszystkim czepka pielęgniarskiego, jako symbolu jej profesji. W toku ewolucji etosu pielęgniarskiego i zniesienia tradycji jednolitego umundurowania pojawił się problem identyfikacji pielęgniarek na tle innych członków zespołu terapeutycznego, czy pracowników administracyjnych placówek ochrony zdrowia. Badania pokazują, iż pacjenci są zdezorientowani. Mają trudności w rozróżnianiu pielęgniarki, od opiekuna medycznego, czy pracowników administracyjnych szpitala, czy innej placówki systemu. Osoby starsze, przyzwyczajone do tradycyjnego stroju pielęgniarskiego, w którym to czepek pielęgniarski był podstawą identyfikacji, mają największe trudności z adaptacją do stanu teraźniejszego, w którym obowiązuje zupełna dowolność w umundurowaniu zawodowym pielęgniarki, a jedynym sposobem jej wskazania jest identyfikator [1].

Badania przeprowadzone na terenie Wielkiej Brytanii zwróciły uwagę na niepokojący proces zachodzący w społeczeństwie. Pacjent w podeszłym wieku widzący pielęgniarkę $\mathrm{w}$ innym stroju niż tradycyjny $\mathrm{z}$ czepkiem na głowie, często kwestionował posiadaną przez pielęgniarkę wiedzę, umiejętności, kompetencję, zaangażowanie, troskę, a co za tym idzie jej profesjonalizm. Wnioski te skłoniły autorów do pogłębienia swoich badań. Powstała skala obrazowania pielęgniarek (NIS - Nursing Incivility Scale), za pomocą której badacze stwierdzili, że nieformalny strój zawodowy pielęgniarki nie przedstawia jej wyraźnej tożsamości zawodowej. Udowodniono także, iż z pojęciem 
Piotr Pawłowski, Paulina Mazurek, Magdalena Zych, Katarzyna Zuń, Beata Dobrowolska

Tab. 1. Opis wyszukanych prac poddanych analizie

\begin{tabular}{|c|c|c|c|c|c|c|c|}
\hline Lp. & Autorzy & Tytuł & $\begin{array}{c}\text { Rok } \\
\text { publikacji }\end{array}$ & Cel badań & $\begin{array}{c}\text { Metoda } \\
\text { badawcza }\end{array}$ & Narzędzia badawcze & Grupa badana \\
\hline 1. & \begin{tabular}{|c|} 
Lehna C., Pfoutz S., \\
Peterson TG., Degner K., \\
Grubaugh K.,Lorenz L, \\
Mastropietro S., Rogers LS., \\
Schoettle B, Seck LL. \\
\end{tabular} & $\begin{array}{l}\text { Nurse attire: indicators of } \\
\text { professionalism. }\end{array}$ & 1999 & $\begin{array}{c}\text { Zbadanie jak obecny } \\
\text { strój pielęgniarki wpływa } \\
\text { na wizerunek zawodu } \\
\text { pielęgniarskiego. }\end{array}$ & Wywiad & $\begin{array}{c}\text { Kwestionariusz } \\
\text { wywiadu, dyktafon }\end{array}$ & $\begin{array}{l}12 \text { pielęgniarek, } \\
1 \text { student I st., } \\
1 \text { dorosły pacjent }\end{array}$ \\
\hline 2. & $\begin{array}{l}\text { Skorupski VJ., } \\
\text { Rea RE. }\end{array}$ & $\begin{array}{l}\text { Patient perceptions of today's } \\
\text { nurse attire: Exploring dual } \\
\text { images }\end{array}$ & 2006 & $\begin{array}{c}\text { Określenie obrazu osoby } \\
\text { pielęgniarki w zależności od } \\
\text { jej umundurowania }\end{array}$ & $\begin{array}{c}\text { Sondaż } \\
\text { diagnostyczny }\end{array}$ & $\begin{array}{l}\text { 13. punktowy autorski } \\
\text { kwestionariusz ankiety }\end{array}$ & $\begin{array}{l}180 \text { dorosłych } \\
\text { pacjentów } \\
\text { szpitala Pacific } \\
\text { Northwes }\end{array}$ \\
\hline 3. & $\begin{array}{c}\text { Albert NM., Wocial L., } \\
\text { Meyer KH., Trochelman K. }\end{array}$ & $\begin{array}{l}\text { Impact of nurses' uniforms } \\
\text { on patient and family } \\
\text { perceptions of nurse } \\
\text { professionalism. }\end{array}$ & 2008 & $\begin{array}{l}\text { Ocena poziomu } \\
\text { profesjonalizmu } \\
\text { pielęgniarki w zależności } \\
\text { od jej stroju. }\end{array}$ & $\begin{array}{c}\text { Sondaż } \\
\text { diagnostyczny }\end{array}$ & $\begin{array}{l}\text { Nurse Image Scale } \\
\text { (NIS), Nurse Image } \\
\text { Scale (NIS) }\end{array}$ & $\begin{array}{l}390 \text { dorosłych } \\
\text { pacjentów, } \\
\text { ich dorosłych } \\
\text { odwiedzających, } \\
109 \text { pacjentów } \\
\text { pediatrycznych }\end{array}$ \\
\hline 4. & $\begin{array}{c}\text { Guidroz AM., } \\
\text { Burnfield-Geimer JL. } \\
\text { Clark 0., Schwetschenau } \\
\text { HM. Jex SM. }\end{array}$ & $\begin{array}{c}\text { The Nursing Incivility Scale: } \\
\text { Development and Validation } \\
\text { of an Occupation-Specific } \\
\text { Measure }\end{array}$ & 2010 & $\begin{array}{l}\text { Ocena rozwoju Nursing } \\
\text { Incivility Scale, jej } \\
\text { aktualności oraz } \\
\text { zastosowania. }\end{array}$ & $\begin{array}{c}\text { Sondaż } \\
\text { diagnostyczny, } \\
\text { walidacja skali }\end{array}$ & $\begin{array}{c}\text { Nursing Incivility Scale } \\
\text { (NIS) }\end{array}$ & 163 pielęgniarki \\
\hline 5. & Castledine G. & Uniformity in uniform & 2011 & $\begin{array}{c}\text { Analiza jednolitości } \\
\text { w umundurowaniu } \\
\text { zawodowym pielęgniarek }\end{array}$ & $\begin{array}{l}\text { Przegląd } \\
\text { literatury }\end{array}$ & - & - \\
\hline 6. & Sharkey V. & Uniform approach & 2012 & $\begin{array}{l}\text { Analiza umundurowania } \\
\text { zawodowego pielęgniarek }\end{array}$ & $\begin{array}{l}\text { Przegląd } \\
\text { literatury } \\
\end{array}$ & - & - \\
\hline 7. & $\begin{array}{l}\text { Albert NM., Burke J., } \\
\text { Bena JF. Morrison SM. } \\
\text { Forney J. Krajewski S. }\end{array}$ & $\begin{array}{l}\text { Nurses' Uniform Color } \\
\text { scheme and Feelings/Emot- } \\
\text { ions in School-Aged Children } \\
\text { Receiving Health Care }\end{array}$ & 2013 & \begin{tabular}{|c|} 
Analiza reakcji emocjonalnej \\
pacjentów pediatrycznych \\
w zależności od kolorystki \\
umundurowania \\
zawodowego. \\
\end{tabular} & $\begin{array}{c}\text { Sondaż } \\
\text { diagnostyczny }\end{array}$ & $\begin{array}{c}\text { Autorski } \\
\text { kwestionariusz } \\
\text { ankiety }\end{array}$ & $\begin{array}{l}233 \text { pacjentów } \\
\text { pediatrycznych }\end{array}$ \\
\hline 8. & $\begin{array}{c}\text { Clavelle JT., } \\
\text { Goodwin M., Tivis LJ. }\end{array}$ & $\begin{array}{l}\text { Nursing Professional Attire } \\
\text { Probing Patient Preferences } \\
\text { to Inform Implementa-tion }\end{array}$ & 2013 & \begin{tabular}{|c|} 
Pogłębienie wiedzy na \\
temat postrzegania \\
profesjonalnego wizerunku \\
pielęgniarki w kontekście \\
umundurowania \\
zawodowego. \\
\end{tabular} & $\begin{array}{c}\text { Sondaż } \\
\text { diagnostyczny }\end{array}$ & $\begin{array}{l}\text { Zmodyfikowana Penn } \\
\text { Interactive Peer Play } \\
\text { Scale (PIPPS) z jednym } \\
\text { pytaniem otwartym. }\end{array}$ & $\begin{array}{l}350 \text { dorosłych } \\
\text { pacjentów }\end{array}$ \\
\hline 9. & $\begin{array}{l}\text { Hoeve tY, Jansen G., } \\
\text { Roodbol P. }\end{array}$ & $\begin{array}{l}\text { The nursing profession: } \\
\text { public image, self-concept } \\
\text { and professional identity. A } \\
\text { discussion paper. }\end{array}$ & 2013 & \begin{tabular}{|c|} 
Omówienie faktycznego \\
wizerunku pielęgniarek. \\
Analiza innych czynników, \\
mających wpływ na rozwój \\
samooceny pielęgniarek \\
i tożsamości zawodowej. \\
\end{tabular} & $\begin{array}{c}\text { Przegląd } \\
\text { systematyczny } \\
\text { dostępnej } \\
\text { literatury }\end{array}$ & - & $\begin{array}{l}1216 \text { artykułów } \\
\text { zakwalifikowano, } \\
18 \text { z nich } \\
\text { spełniło kryteria } \\
\text { włączenia do } \\
\text { analizy. } \\
\end{array}$ \\
\hline 10. & $\begin{array}{l}\text { Porr C., Dawe D., } \\
\text { Lewis N., Meadus RJ., } \\
\text { Snow N., Didham P. }\end{array}$ & $\begin{array}{c}\text { Patient perception of } \\
\text { contemporary nurse attire: } \\
\text { A pilot study }\end{array}$ & 2014 & $\begin{array}{l}\text { Analiza opinii pacjentów } \\
\text { dot. munduru pielęgniarki }\end{array}$ & \begin{tabular}{c|} 
Sondaż \\
diagnostyczny \\
(badania \\
pilotażowe) \\
\end{tabular} & $\begin{array}{l}\text { Modificated Nurse } \\
\text { Image Scale (MNIS) }\end{array}$ & $\begin{array}{l}46 \text { adult surgical } \\
\text { patients }\end{array}$ \\
\hline 11. & $\begin{array}{l}\text { Küçüka L. Çömeza T., } \\
\text { Kaçarb S., Sümelib F., } \\
\text { Taşkıran Ö. }\end{array}$ & $\begin{array}{l}\text { Psychiatric Patients' } \\
\text { Perspective: Nursing } \\
\text { Uniforms. }\end{array}$ & 2015 & $\begin{array}{c}\text { Badanie wpływu } \\
\text { kolorystki umundurowania } \\
\text { zawodowego } \\
\text { pielęgniarki na pacjenta } \\
\text { hospitalizowanego } \\
\text { psychiatrycznie } \\
\end{array}$ & $\begin{array}{c}\text { Sondaż } \\
\text { diagnostyczny } \\
\text { (badania } \\
\text { przekrojowe) }\end{array}$ & $\begin{array}{l}\text { Nursing Uniform } \\
\text { Catalog }\end{array}$ & $\begin{array}{l}257 \text { dorosłych } \\
\text { pacjentów } \\
\text { leczonych } \\
\text { psychiatrycznie }\end{array}$ \\
\hline
\end{tabular}

pielęgniarskiego dress code wiąże się bezpośrednio aspekt postrzegania osoby pielęgniarki jako wykwalifikowanej, kompetentnej do wykonywania czynności związanych $\mathrm{z}$ wybraną profesją. Pacjenci będący podmiotem pielęgniarskiej opieki często szukają dowodów potwierdzających kompetencję, uczciwość oraz troskę w niewerbalnych komunikatach wysyłanych przez osobę pielęgniarki. Są to między innymi jej styl umundurowania zawodowego, aparycja, posiadanie tatuaży, kolczyków, a nawet długość włosów. Powszechnym zjawiskiem u pacjentów przyjmowanych na oddział szpitalny jest lęk przed hospitalizacją.
Pacjent oczekuje wskazówek, jawnych znaków, często wręcz dowodów, zapewniających go o autorytecie, wysokim poziomie etyki zawodowej, a przede wszystkim profesjonalizmie osób sprawujących nad nim opiekę. Liczne badania dotyczące postrzegania pielęgniarek przez pacjentów, dowodzą, iż poziom ich kompetencji i profesjonalizmu w oczach pacjentów opiera się na pierwszym wrażeniu, rzutującym w przyszłości na poziom jego zaufania do osób sprawujących opiekę, a co za tym idzie wytworzenie wysokojakościowej relacji terapeutycznej [2]. 


\section{Kolorystyka umundurowania pielęgniarskiego - wpływ na opinię pacjenta}

Kolorystyka umundurowania pielęgniarskiego jest ważnym elementem w kreowaniu opinii odnośnie osoby pielęgniarki w percepcji pacjenta oraz jego rodziny. Küçük L. i wsp. stworzył katalog 8 wzorów mundurów pielęgniarskich, różnorodnych pod względem kolorystyki oraz tekstury tkaniny, za pomocą którego badano preferencje pacjentów z zaburzeniami psychicznymi odnośnie umundurowania pielęgniarskiego. Blisko jedna trzecia respondentów (31\%) badania preferuje biel jako kolor charakterystyczny dla pracowników placówek ochrony zdrowia. Autorzy jako przyczynę tego stanu przytaczają argumenty, iż biały mundur w odbiorze pacjenta świadczy o profesjonalizmie pielęgniarki, a także posiadaniu przez nią adekwatnej wiedzy i doświadczenia, przekładającego się na skuteczność w działaniu oraz wysoki poziom pewności siebie. Ponadto biel identyfikowana jest z czystością oraz higieną, co wpływa na wysokie poczucie epidemiologicznego bezpieczeństwa podmiotu opieki. Co więcej, we wszystkich wyznaniach i ruchach wyznaniowych biel utożsamiana jest z czystością, łagodnością, wręcz świętością, co umożliwia pielęgniarce sprawowanie opieki holistycznej, opartej na zaufaniu oraz właściwej komunikacji, uwzględniającej duchowy aspekt opieki. Interesujący jest także fakt, iż w przeprowadzonym badaniu aż 15\% respondentów wskazało preferencję ubioru cywilnego pielęgniarek, motywując swój wybór barierami komunikacyjnymi, zakłócającymi powstanie relacji między pacjentem a członkami zespołu pielęgniarskiego [3].

Same pielęgniarki również preferują biel jako kolor charakterystyczny dla pracowników systemu ochrony zdrowia, pozwalający także na ich łatwą i szybką identyfikacje spośród innych pracowników placówek medycznych [3].

Lehna i wsp. w badaniu jakościowym, wykorzystującym metodę wywiadu swobodnego z 12 pielęgniarkami i 1 pacjentem, udowodnili zależność między białym umundurowaniem a łatwością identyfikacji. Pacjentka będąca respondentem badania była zdezorientowana, kiedy pielęgniarki nie posiadały odzieży ułatwiającej ich identyfikacje. Również pielęgniarki biorące udział w badaniu uznały strój zawodowy za ważny aspekt ich identyfikacji [4].

Porr C. i wsp. przeprowadzili badania mające na celu określenie jak pielęgniarski dress code wpływa na profesjonalizm oraz postrzeganie osoby pielęgniarki. W badaniu wzięło 449 pacjentów w różnym wieku. Jako narzędzie badawcze zastosowano zmodyfikowaną skalę obrazowania pielęgniarek (Modified Nurse Image Scale) z 10 cechami wpływającymi na profesjonalizm, wśród których znalazły się: pewność, kompetentność, uważność, sprawność, troska, przystępność, rzetelność, profesjonalizm, zdolność do współpracy, empatyczność. Każdemu z respondentów zaprezentowano fotografię, którą następnie należało ocenić według zastosowanej wyżej wymienionej skali. Analiza przeprowadzonych badań ukazała pewne zależności, między kolorystyką, teksturą umundurowania, poziomem 10 cech związanych z profesjonalizmem zawodu pielęgniarki. Najwyższe wyniki uzyskały odcienie bieli. Stosunkowo wysokie wyniki w poziomie odpowiednich cech uzyskał jednolity mundur w odcieniach niebieskiego identyfikowany również z osobą budzącą duże zaufanie. Najniższe wyniki uzyskały mundury mające różnorodną, kolorową teksturę $[1,5]$

\section{Wiek jako zmienna determinująca preferencje w pielęgniarskim dress code}

Badania Skorupski i wsp. pokazują zależności między wiekiem a preferencjami co do umundurowania zawodowego pielęgniarki. Na podstawie uzyskanych danych empirycznych wyciągnięto wniosek, iż osoby z pokolenia baby boomers oraz seniorzy utożsamiają pielęgniarki z białym strojem. Ludzie młodsi natomiast w celu rozpoznania pielęgniarek korzystają z identyfikatorów bądź odznaczeń znajdujących się na ich mundurach w Wielkiej Brytanii oraz Stanach Zjednoczonych. Ponadto w badaniu tym dokonano także oceny wybranych mundurów pielęgniarskich wykorzystując zmodyfikowaną przez S. Mangum, skalę NIS (Nursing Incivility Scale). Jej modyfikacja pozwoliła wskazać zależności, w jaki sposób tekstura oraz barwa umundurowania wpływa na cechy, jakie odbiera w swej percepcji pacjent, będący podmiotem pielęgniarskiej opieki. Z otrzymanych danych liczbowych wywnioskowano, że najmniej pożądanym przez pacjentów mundurem jest mundur jednolity, bez jakiejkolwiek tekstury, w kolorze innym niż biel $[2,6]$.

Albert N. M. i wsp. przeprowadzili badania odnośnie wpływu stylu umundurowania zawodowego pielęgniarek na opinie pacjentów. Respondentami badania byli dorośli oraz dzieci. Wiek stanowił zmienną niezależną, za pomocą, której przedstawiono różnicę w percepcji pielęgniarek przedstawionych na fotografiach [7]. Wśród dorosłych najwyższy wynik (25\%) uzyskało białe umundurowanie pielęgniarek, najniższy wynik natomiast mundur, na którym można dostrzec wyraźny wzór tkaniny. Odmienne wyniki uzyskano w grupie pacjentów pediatrycznych, w których najwyższy wynik (22\%) uzyskał wzorzysty top $\mathrm{z}$ białymi bądź niebieskimi spodniami $[7,8]$.

\section{Inne ważne aspekty wizerunku pielęgniarki rzutujacce na jej postrzeganie w oczach hospitalizowanego pacjenta}

W badaniu przeprowadzonym przez Clavelle J. i wsp., w którym udział wzięło 350 pacjentów, wykorzystano metodą sondażu diagnostycznego. Narzędziem badawczym stał się kwestionariusz ankiety zawierający 13 pozycji z PIPPS (Penn Interactive Peer Play Scale) gdzie 4 z nich odnoszą się do profesjonalizmu pielęgniarki, $5 \mathrm{z}$ nich porusza problematykę preferencji pacjentów odnośnie stylu ubioru. Każdą z 13 pozycji kwestionariusza respondent oceniał w skali Likerta od 1 do 10 , gdzie 1 oznaczało „zdecydowanie się nie zgadzam”, a 10 - „zdecydowanie się zgadzam”. Ponadto w kwestionariuszu ankiety umieszczono jedno pytanie otwarte: „Czy według Pana/ Pani jest coś jeszcze, na co należy zwrócić uwagę przy ocenie stroju pielęgniarek?" Celem badań było ukazanie czy strój pielęgniarki wpływa na jej postrzeganie w percepcji pacjenta jako profesjonalisty. Po przeanalizowaniu wyników wyciągnięto ogólne wnioski. Pacjenci ponad kolorystykę umundurowania, stawiają wiele innych cech, 
koncentrując się na schludności wyglądu pielęgniarek, odnoszącej się do wyprasowanego, niepomiętego munduru, a także czystego obuwia. Ważnym aspektem stała się długość włosów, która według pacjentów nie powinna przekraczać poziomu ramion. Pielęgniarki posiadające mocny makijaż, piercing ciała, tatuaże, długie paznokcie, stosujące mocne perfumy oraz duża ilość biżuterii postrzegane były jako mniej empatyczne, niecierpliwe, posiadające niższy poziom umiejętności oraz kompetencji, choć wyżej wymienione elementy wyglądu zewnętrznego nie były zbyt popularne wśród badanych pielęgniarek. Analizowane badania pokazały, iż komfort pielęgniarek jest dla pacjentów istotną wartością w planowaniu strategii dress code, ponieważ jego poziom bezpośrednio rzutuje na jakość świadczonych usług [9].

\section{OMÓWIENIE}

W krajach Europy Zachodniej oraz w Stanach Zjednoczonych wprowadzenie zasad dress code wiązało się $\mathrm{w}$ przeszłości z wieloma kontrowersjami. Do chwili obecnej strategie jednolitego umundurowania zawodowego pielęgniarek mają swoich zwolenników jak i przeciwników. Jako główny problem we wprowadzeniu pielęgniarskiego dress code, przytaczanym w literaturze jest konieczność jego aktualizacji. Ważne jest, aby mundur pielęgniarski podążał za trendami, szeroko rozumianą modą, a przede wszystkim był praktyczny, nie ograniczający ruchów, zapewniający bezpieczeństwo zarówno pacjentowi jak i samej pielęgniarce. Drugim z argumentów przeciwników wprowadzenia ujednoliconego umundurowania pielęgniarek jest opinia, iż pielęgniarstwo to zawód opiekuńczy, wymagający od osób go wykonujących interdyscyplinarnych umiejętności z zakresu nauk medycznych oraz społecznych, a sam fakt posiadania odpowiedniego munduru nie wpływa na posiadanie tych umiejętności [10].

Wprowadzenie zasad dress code pielęgniarek wiąże się także z dodatkowymi, wysokimi kosztami zakupu nowych ujednoliconych strojów. Znalezienie dodatkowych funduszy na ten cel byłoby możliwe jedynie przy wsparciu pracodawcy oraz rządu. Aktualnie pielęgniarki w krajach zachodnich, takich jak na przykład Wielka Brytania umundurowanie otrzymują właśnie od pracodawcy, w postaci 5 tunik bądź bluz medycznych oraz 3 par spodni. Wszelkie koszty jego utrzymania, w tym także koszt utrzymania munduru w czystości, mają prawo odliczyć od podatku dochodowego, potrąconego w rocznym zeznaniu podatkowym $[11,12]$

Kwestia umundurowania pielęgniarek jest aktualnym problemem liderów pielęgniarstwa. Wiele placówek organizacyjnych systemu opieki zdrowotnej wciąż zastanawia się nad wprowadzaniem zasad dress code obowiązujących wszystkich przedstawicieli zawodów medycznych, ułatwiając tym samy ich identyfikacje. Wybór pielęgniarskich strojów może pozytywnie wpłynąć na poważanie społeczne danej placówki, postrzeganie pielęgniarek i liderów zarządzających zespołami profesjonalistów. W związku z powyższym ważne jest, aby strategia wprowadzenia zmian w umundurowaniu posiadała cechy procesu zorganizowanego, była przemyślana i konsekwentna [13].

\section{WNIOSKI}

1. Istnieje związek między wyglądem zewnętrznym pielęgniarek w pracy a ich wizerunkiem zawodowym. Znaczenie ma styl umundurowania, jego kolorystyka, estetyka i jednolitość umundurowania w placówce opieki zdrowotnej.

2. Istnieje także zależność między wyglądem zewnętrznym pielęgniarki w pracy a postrzeganiem przez pacjentów jej kompetencji zawodowych i poziomu profesjonalizmu.

3. Umundurowanie pielęgniarek w placówce opieki zdrowotnej może stanowić istotny element polityki wizerunkowej zarówno tej placówki systemu ochrony zdrowia jak i samej grupy pielęgniarek.

\section{REFERENCES/PIŚMIENNICTWO}

1. Porr C, et al. Patient perception of contemporary nurse attire: A pilot study. Int J Nurs Pract 2014; 20: 149-155.

2. Skorupski VJ, Rea RE. Patient perceptions of today's nurse attire: Exploring dual images. JONA 2006; 36: 393-401.

3. Küçük L, et al. Psychiatric Patients' Perspective: Nursing Uniforms. ARCH PSYCHIAT NURS 2015; 29: 383-387.

4. Lehna C, et al. Nurse attire: indicators of professionalism. J Prof Nurs 1999; 15(3): 192-199.

5. Hoeve TY, Jansen G, Roodbol P. The nursing profession: public image, self-concept and professional identity. A discussion paper. JAN 2013; 70(2): 295-309.

6. Guidroz AM, et al. The Nursing Incivility Scale: Development and Validation of an Occupation-Specific Measure. J Nurs Meas 2010; 18 (3): 176- 201.

7. Albert NM, et al. Impact of nurses' uniforms on patient and family perceptions of nurse professionalism. Appl Nurs Res 2008; 21: 181-190.

8. Albert NM, et al. Nurses' Uniform Color scheme and Feelings/Emotions in SchoolAged Children Receiving Health Care. J Pediatr Nurs 2013; 28: 141-149.

9. Clavelle JT, et al. Nursing Professional Attire Probing Patient Preferences to Inform Implementation. JONA 2013; 43 (3): 172-177.

10. Castledine G. Uniformity in uniform. Br J Nurs , 2011; 20 (6): 389

11. Brighton and Sussex University Hospitals Dress Code Policy: www.bsuh.nhs.uk/wp content/uploads/sites/5/2016/09/BSUH-Uniform-Dress-Code-Policy.pdf [access from 31/01/2019].

12. Dress Code and Uniform Policy: www.medway.nhs.uk/downloads/4401\%20-\%20 Dress\%20Code\%20and\%20Uniform\%20Policy.pdf [access from 31/01/2019].

13. Sharkey V: Uniform approach. Nursing Standard 2012; 26 (45): $26-27$.

Manuscript received/Praca zgłoszona do czasopisma: 18.02.2019

Manuscript accepted/Praca zaakceptowana druku: 11.03.2019

Translation/Tłumaczenie: Beata Chrust 